Original Article (short paper)

\title{
Sport as a vehicle for socio-educational transformation: a study of the Fernanda Keller Project
}

\author{
Manuella Lopardi Steigleder ${ }^{1}$, Roberto Ferreira dos Santos ${ }^{1}$, \\ Carlos Alberto Figueiredo da Silva ${ }^{1}$ \\ 'Universidade Salgado de Oliveira, Niterói, RJ, Brasil.
}

\begin{abstract}
Aims: The aim is to identify the representations of the main actors involved in the Fernanda Keller Project on the internal and external environments of the organization. Methods: Data were collected through observation, indepth interviews, semi-structured interviews and focus groups. Results: Findings points to the great difficulty of the interaction between the Project and the city hall, from a certain moment. In the internal environment, stand out the value attributed to the Project in the social transformation of young people, community, and professionals directly or indirectly involved in the actions. Conclusion: The project has achieved success and social impact. However, the participation of the city hall of Niterói has diminished with the passage of time. Despite the difficulties encountered, the project has found new partners in the private sector. The initiative to seek other means to obtain resources was fundamental to the project's maintenance. This posture has led everyone to a positive and involving message that permeates all the reports that this study analyzed.
\end{abstract}

Keywords: sport, social sports project, local development, physical education.

\section{Introduction}

Social sports projects have been investigated with a focus on motor development and school learning ${ }^{1-5}$. Other studies direct their attention to the influence of these actions on the daily life of children and young people ${ }^{6-9}$. These projects have the sport as an anchor to attract people to participate in the activities.

However, initiatives that seek at the same time the formation of the citizen, professionalization for the job market in the project sports field, and the eventual career of the athlete have been little studied in Brazil. Some reasons may be given, among them: a) the focus of some social sports projects is on increasing self-esteem and improving learning, but not on future professionalization of young people; b) in other cases, the focus on the development of athletes, but not on the development of citizenship or future professionalization; c) the focus on cognitive development, but not concomitantly sports and professionalization.

Among the few initiatives that combine citizenship, professionalization and sport are those developed in the city of Niterói, known as Projeto Nomes. This study focuses on the Fernanda Keller Project, developed in the city of Niterói, located in the state of Rio de Janeiro, Brazil. In 1996, Niterói prefecture devised the Projeto Nomes, whose objective was to create social sports projects, and these linked to sportsmen and sportswomen of famous names of the city as a way to captivate children from the public network or neighborhoods.
Since 1988, the Constitution of Brazil has become sports and leisure as the right of all Brazilian citizens. This is also guaranteed in all state constitutions and organic laws of municipalities ${ }^{10}$. Although it is a constitutional right, we are far from seeing it assured effectively. Social participation is essential as instruments of action and it may be possible to move towards the consolidation of public policies in the area of sport.

As the right of all citizens to sport and leisure, the State must guarantee conditions for these activities. Previous study has shown that this right is not being respected and guaranteed to the citizen ${ }^{11}$. It is needed and especially those that refer to social rights, as is the case of sports and leisure.

There is no public policy for sports capable of meeting the interests and needs of society at moment ${ }^{12}$. It is necessary and imperative for the public administrators to encourage sports leisure as one of the most modern forms of manifestation of the social impact of sport ${ }^{13}$. Sports competitions result in special sum of the arrangements, allowing sports as a choice of life, favoring inclusion ${ }^{14}$. However, criticisms that sports public policies would need other justifications other than just democratization of access/permanence ${ }^{12}$.

In the various manifestations of the sport, we find different meanings and different intentions that differ from the goals, expectations, and needs of its practitioners ${ }^{13}$. It must be considered that within each of these forms of manifestation there are also a variety of the goals. Sport is 
placed in the school and non-formal systems of education as a component of the process of socialization and professionalization of poor sectors, especially for the young population ${ }^{14}$. In this way, it contributes to the fight against social exclusion, which has its roots in poverty, inadequate housing and unemployment. We are facing with different manifestations of sports culture. When it comes to investigating them through scientific knowledge, constant observation is required for the various models of interpretations. Thus, the new definitions for a more inclusive life, social coexistence, and social consciousness require recognition of one of the most significant values of contemporaneity: the acceptance of plurality, and also of the differences, of the specificities and their singularities ${ }^{15}$.

Teachers have an essential function that is an affirmation by the positive, the construction, the projection, the implementation, the realization of ideas and actions ${ }^{16}$. We can not be breakers or discourages but builders and supporters; we must sow the dream of construction, optimism in difficulty, barriers and obstacles, sweat and effort, confidence in the capacity for action and achievement. Facing the situation of children and adolescents' victims of poverty, inequality and social exclusion, there was an increase in the number of projects parallel to formal education in which they could provide support and assistance to these children and adolescents since 1980. It also affirms that parents and professionals in social projects perceive them as spaces in which children take care of themselves, protecting them against drugs, the evils of the street is belevied cto come from the idle time ${ }^{17}$.

When designing social projects in the area of physical education, sports, and leisure, the communities should be given the knowledge and conditions to exercise citizenship in their fullness, preparing the subjects of these communities in a way that they could acquire a power of social and political representation ${ }^{18,19}$. However, the reductionist and discriminatory view about leisure opportunities open the way to social projects that find physical, sports, and leisure education as a palliative for society's ills. Thus, projects that are opportunistically identified as 'talent search' may be associated with a lack of adequate planning, contributing to the discrediting of many social projects in this area ${ }^{20}$.

The main question is why to study the Fernanda Keller project? In our exploration of the field surveyed, a significant representation appeared in the relationship between the Institute responsible for the project and the city hall of Niterói. In other studies ${ }^{8,9}$, we verified a high dependence of these organizations on the financial contribution of municipalities, states, and the Union. The anchor for these projects to be maintained is the legislation that encourages sports. However, when we hear the people who work on the Fernanda Keller Project and Fernanda herself, we realized how determined they are to find other ways to get the resources they need.
In addition, the Fernanda Keller Project is concerned with citizen education, future professionalization in the area, and athlete training. As already pointed out, there is a gap in Brazilian studies on social sports projects that present such characteristics.

The study of the Fernanda Keller Project reveals another way that can be traversed by these organizations, without dependence on the political incentive. Describing these actions and the representations of their main actors contributes to a better understanding and improvement of these social inclusion actions.

The study of social sports projects constitutes an opportunity to verify the appropriation of the different knowledge built and exchanged in the relational processes of interpersonal interaction, and if the community values them. These results can contribute effectively to the improvement of these initiatives and their impacts on the lives of people directly or indirectly related to them.

The objective of this study is to identify the representations of the main actors involved in the Fernanda Keller Project about the internal and external environments of the organization, in order to understand the perspectives that are presented in its development.

\section{Methods}

The data collection took place during eight months in Forte Barão do Rio Branco, Niterói. The activities that were accompanied by the researchers included swimming, running and cycling. During this period there were: a) the systematic observation; b) the in-depth interview with the manager Fernanda Keller; c) semi-structured interviews with two coordinators and four teachers; d) focus group with eight students.

The observation period took place between March and July 2013. Twice a week, researchers went to Forte Barão de São João and toured the sectors of the investigated project. Informal conversations, comments between students and teachers, spontaneous statements, and the description of the activities developed made up in the field diary.

The interviews with Fernanda Keller, coordinators, teachers, and students took place between August and October 2013.

The categorization of the index terms that emerged in the interviewees' discourses was based on the assumptions of $\operatorname{Bardin}^{21}$ : a) an index term could not be susceptible to compose more than one category; b) the categories were constructed so as not to allow terms with different meanings to be part of the same category; c) the categories were created after the analogical classification of the index terms, so that they were adapted to the data; d) The aim was to avoid that an index term could be categorized in different ways, establishing the criterion of confrontation and entry into the category. 
In the analysis of the focus group, the word association technique, being represented by $\operatorname{Bardin}^{21}$, was intended to identify nuclei of meanings of representations. According to Rangel ${ }^{22}$, it is possible to recognize the nuclei of representation in the induced words and capture the central and peripheral representational elements about the meaning of sport from the inductive phrase: "Quickly write five words that, in your opinion, are associated with the sport". These words were annotated and then numbered in order of importance in the design of the research subjects. The word association method refers to a current situation of the psyche of the individual in question, where the stimulus word brings to reality a situation linked to it. Usually, the attitude towards the chosen stimulus word is the same as that attitude whose person has in a real life.

A classification grouping process initially organized words collected in the free word association test, clustering the next words (identical or synonymous words) and then subjected to an approximation classification, establishing analysis categories ${ }^{23}$.

The word association technique helps to identify areas of blocking and repression of an individual, allowing the spontaneous appearance of associations related to the words tested ${ }^{21}$.

The research subjects were chosen based on the following aspects: 1) Fernanda Keller was and is the mentor and serves as the primary leader; 2) coordinators work on the project from the beginning; 3) four teachers were students of the project when they were young; 4 ) the students who made up the focus group have been on the project for at least 3 years.

The research is descriptive with a qualitative approach. The immersion in the field of study guided the actions of this study, seeking to capture the daily life of the project, as well as the experiences and relationships that arose from the activities developed. It was sought to give meanings to the research data with the help of the participants themselves, contextualizing the interpretations from their visions. In this way, the analysis was carried out with the subjects of the research.

In the focus group, the use of the technique of association of words has the interest to identify the principal ideas of meanings of the ideas. It is possible to recognize the core of perceptions in the induced words and to capture the central and peripheral elements on the meaning attributed to the project from the inductive phrase. The method of association of words concerns a current situation of the psyche of the individual in question, where the word stimulus brings to reality a situation related to it. Usually, the attitude toward the stimulus word chosen is the same as that person's attitude in real life ${ }^{18}$. The words collected in the test of free association of the words were initially organized by the process of grouping by classification, agglomerating the next words (words identical or synonymous) and then submitted to a classification by approximation, establishing categories of analysis.

From the survey participants, it was asked to analyze the completed report of the collected data, in order to rectify any misinterpretation that might exist. Only those who agreed to sign the Informed Consent Term (TCLE) participated. The study was approved by the Ethics Committee (Platforma Brasil), under the number: 442049.

\section{Results and Discussion}

Conceived in 1998 by the triathlete Fernanda Keller and her mother Terezinha Keller, the Fernanda Keller Institute during its 20 years has welcomed more than 6,000 children and young people in its programs. It attends, annually, an average of 400 children and young people from the public low-income education system, in which they participate in the actions of the Institute's projects.

The Instituto Fernanda Keller's mission is social education, through sports, promoting the socialization and social integration of children and youth based on integrated actions involving sports, health, leisure, and entertainment.

\section{Profile of beneficiaries}

The students are children and adolescents, between the ages of 7 and 18. All students are of the public school system; $80 \%$ of the children and adolescents attending the Institute are residents of the following communities: Charitas (Morro do Preventório), Jurujuba and Morro do Cavalão, and $20 \%$ of the children and adolescents attending the Institute are residents of the following communities: Barreto, Fonseca, Caramujo, Santa Bárbara and Morro do Céu.

As most students live in the neighborhood of Jurujuba and surrounding areas, they do not use transportation. Those residing in more distant neighborhoods use public transportation (buses), paying passage, this is also a great difficulty faced by these children and young people who are often forced to abandon the project due to lack of financial conditions.

\section{Employee profile}

The Fernanda Keller Institute is made up of people engaged in education and who identify with the triathlon sport. Its staff consists of a chief executive officer, vice president, and chief financial officer; a secretary and the rest of the staff. Among the teachers, three are former students. There are a total of 23 employees. The Institute counts on the participation of fellows (eight) - of undergraduate courses in nutrition, medicine, and nursing, of the technical cooperation agreements with two universities in Niterói. 


\section{Main financiers}

The Fernanda Keller Institute is sponsored by a broad international foundation and has a support network, as well as donations from individuals. Municipal and federal agencies also participate with the assignment of space, provision of snacks and administrative support. The industry linked to the bicycles sector supports with uniforms, logistical support in events and tournaments, a field of training and donation of material. Two higher education institutions support courses and research.

\section{Analysis of the interview with Fernanda Keller}

Fernanda Keller, the founder of the project always had a dream of being able to share all her achievements in the sport. Fernanda was often champion of the most significant and most challenging triathlon championship in the world.

Category 1: Financial Support. Twenty years before this social sports work, Keller reports that despite the great satisfaction in being able to offer some of the sport to the children, her most significant difficulty is the financial support. Currently, with few resources, the project is maintained through the sponsorship of an international foundation. In her testimony, she explicitly expresses her dissatisfaction with the current system. The government, in agreement with its report, needs to make changes in the application of the funds, because they exist. It is necessary to have transparency, smoothness and proper policies for the sport to be truly fulfilled.

\footnotetext{
We are now asking for these demonstrations; there is no point in coming any more money, you have to change the system, understand? The system has to change; there is money; that is what people are not understanding. It is that they think that this money does not have. Has! It is not done what has to be done. It does not get there. (Keller)
}

Category 2: Sport and Social Inclusion. Keller's view finds support in the thinking of Marcellino ${ }^{10}$ when he says that very little has been done in the sector. During the interview, Keller showed that being a recognized athlete facilitates access to people, as entrepreneurs, achieving greater mobilization and better interaction in this category. Emphasizes that she advocates inclusion since sport, in his view, is an instrument that provides social inclusion and it is for this reason that until today he has been struggling.

At the beginning of Projeto Nomes, in which Keller's project was included, there was the intention of designing the city with prominent names of the sport that represented Niterói and that could be children's idols. It consisted of five great athletes, and one of them was Keller. The mayor believed that the children could seek in these idols the dream of being an athlete as well. However, there is a misconception that in order to have an active sportive population, we need sports heroes who would act as an example ${ }^{19,20}$.
After a few years, when the administration changed the city hall, the way of maintaining the project was changed, since the money transfer was being done incorrectly. Feeling that there was a political interest, rather than fostering the project, Keller sought her resources.

\section{Analysis of the interview with the Coordinators}

Two coordinators form part of the coordination of the Fernanda Keller Institute. They have been on the project since its inception. One coordinates the technical part of the Institute and the other the pedagogical part. In this way, they create a path, together, to achieve the institutional mission.

Category 3: Sport and Science. The technical coordinator (TC) emphasizes the issue of the Fernanda Keller Project being something more global. The work done is not only the learning of triathlon sport but the question of citizen training. Lectures are given on the nutritional, medical, and even behavioral aspects.

Azevedo and Gomes Filho ${ }^{14}$ affirm that sport is currently being widely recognized and accepted in communities throughout the world as a science, since there is a connection with medicine, psychology, sociology, sports pedagogy, among others.

Category 4: Sport Policy. TC believes that the project has collaborated in the lives of many young people. For years, struggling for this project to be always working, the coordinator ensures that the greatest difficulty is to have financial support. He reports that in Brazil there is no decent sports policy:

\footnotetext{
Physical education in schools is not what we think it could be; we do not have physical education in the communities. What I miss is not even the only support for the Project; it's the support for the sport; people give themselves a little more. If we had a basic sports policy the thing would already have another course, it would improve in other situations, so what I miss yes is a little more support, but that is not why we will stop doing. (TC)
}

In addition to acting in several sectors, the coordinator is responsible for the technical part of guiding the teachers, passing their experiences and knowledge. However, it emphasizes that the primary objective of the project is socialization, integration and the formation of the full individual. That is why he says:

What I think is fundamental is that when they leave, in three, four or five years, they will leave with another formation, with another mentality through sport, but that they lead to their lives. (TC)

The pedagogical coordinator (PC) points out that sport also has great relevance and importance in the lives of those children. Its primary function is to develop in students' and teachers' critical sense, self-esteem, improve and strengthen children giving them 'empowerment'. For Rangel $^{18}$, social participation is understood to belong and to decide on something. Correia ${ }^{20}$ states that in social projects in the area of Physical Education, sports and leisure, 
knowledge must be given to communities, conditions to develop their citizenship in order to acquire authority, autonomy, and power of social and political representation.

PC in his work gives importance to the achievements and skills of the child, and the teacher must develop them during the activities; social inclusion and diversity should always be present and are considered as principles of the project.

Reinforcing Category 1: Financial Support. PC sought new partners to expand the service. Through the partnership with a public university, students of the courses in nutrition, nursing, and medicine were selected to follow the work, which came to strengthen the actions. It also sought partnership with a private university, which offers scholarships for students who intend to enter higherlevel courses. During her explanation, PC reports her dissatisfaction with the financial relationship with the city hall, since there are always requirements that were not previously agreed and with this, the project was stuck to actions that did not fit the principles of the project. The transfer of the money should be direct and not through cooperatives and foundations, thus having disagreements with the applicability of resources coming from the city hall. The city hall continues with only administrative support in the project. The project tries to gain sustainability through other resources.

The indignation of $\mathrm{PC}$ is visible in his speech:

We pay attention; we send a photo, we send the receipt of a teacher, send everything. However, so you will no doubt what is being done nothing. Because then I go home because the salary of the third sector is not that a wonderful world. (PC)

The coordinator realizes that the teacher, besides his ideal, is also a professional and therefore should be valued and respected:

Professor is insane; because he takes work home, is always thinking about children, brings a ton of things and does not earn proportionally well. (PC)

His indignation goes beyond saying that the State has to offer physical activities, leisure and opportunities so that children can develop their potential and not live on the fringes, without perspective, and without opportunities. For PC, these children do not feel deserving of the rights they have. Bracht ${ }^{24}$ tells us that the State has reasons to intervene and interact with the sports organization, but in reality, these interests are not enough to act in the daily life of sports organizations. The State has to guarantee conditions for sports practices.

\section{Analysis of the interview with the teachers}

Four teachers were interviewed. Everyone had the chance as children to participate in the Fernand Keller Project as students. Throughout these years, they have been able to take advantage of the opportunity that the place offers to enter the university and with that, they became teachers of Physical Education.

Category 5: Better Citizen Through Sport. Teacher $\mathrm{JJ}$ highlights the importance of the project as a trainer of citizens because of his experience and experience as a student is rich and transformative:

Initially I started taking care of the bikes here of the project, and today I am one of the oldest teachers, I work here about 13 years. $(\mathrm{JJ})$

According to JJ, the primary tool of the Fernanda Keller Project is the friendship with the students; it is always to be ready to understand the difficulty that children experience outside of class:

The project's mission is to train the citizen, to offer the practice of sports so that they have new perspectives on life. We are not great athletes, but we have become better citizens through sport. (JJ)

The triathlon has been and is part of the life of Teacher RR since childhood. As a student of the project, he had the opportunity to participate in many championships and many trips through Brazil. However, today, graduated in Physical Education and teacher of the Project Fernanda Keller, RR says that he is a good professional, since he had many experiences as an athlete, thus helping children to achieve their goals. RR emphasizes the importance of this project in his life:

Where I come from, few people had opportunities to do what I am doing: a college. Most of my friends went the wrong way; I managed to be one more in the crowd. The sport was what changed my life, why cannot change their lives? (RR)

The teacher reports that if he had not known the sport, there would be few chances to be part of the Project today. He says that the mission of the project is to help children on a decent path. Being a great athlete is a consequence; the important thing is to develop sincerity and respect. Mitler ${ }^{25}$ says that sport contributes to combating social exclusion, which is rooted in poverty, inadequate housing, and unemployment.

Teacher TT reveals that her practice is educational because of its teachers beyond the technical part: personal hygiene and care with the material. He also says that many students are mirroring their teachers because they know their life trajectories:

\footnotetext{
This sport, this project itself, as I have already mentioned, works all the points in a human being. I am what I am today; I say $80 \%$ thanks to the Project. The citizen that I am, woman, mother, I owe a lot to the Fernanda Keller Institute and to the professionals who were here, trying not to form the athlete, because here we do not aim at this, but the main point is to educate the citizen. (TT)
}

Teacher KK says that providing group lessons, group work and partnership is that the goal of socializing is achieved. Although triathlon is an individual sport, many are the ways worked for there to be that socialization. The 
complicity, the friendship and the respect for the neighbor are always present in the activities that the teacher offers to its students. Also for KK, a teacher who began her activities in the project as a child at ten years of age, the sport is a tool for the cultural environment, for the care of the environment and development with the family. All these positive factors of the sport are supported in the literature, mentioning that sport is an aggregator, unifying, collaborating with all dimensions of the human being, i.e., cultural, mental, spiritual, psychological and social $^{1,2,4,6,8,9}$.

KK says that although the project is aimed at the neediest children, this does not preclude children from the private education network from participating. According to the experiences of this teacher, the sports also generates dedication, effort, and concentration, this is all necessary for general learning, both for sport and for life at school, at work and with the family.

\section{Focal group interview}

In this analysis, the word association technique was used. In the analysis of the structure of representations, we sought to understand the central and the peripheral scheme of ideas.

Category 6: Challenge, Fun, and Companionship. The core of the ideas was composed of the categories challenge, fun, and companionship. As for the idea of the challenge, possible associations with warrior and victory were observed. Concerning the idea of fun, this was associated with leisure. The ideas of companionship prevailed, adding the ideas of friendship and coexistence to companionship, health, energy, quality of life, physical shape, disposition, and optimal nutrition. The sports idea appears with less force in the reports, was narrated from the ideas of swimming, running, triathlon, physical exercises, and soccer. Regarding the impact of this project on their lives, the association of words demonstrated that it is in the social sphere the most considerable influence in the daily life of the participating students. There is no way to promote inclusive social practices without guaranteeing opportunities for social participation. Rangel ${ }^{22}$ understands social participation in two important ways: belonging and deciding on something. Given this same view, Azevedo and Gomes Filho ${ }^{14}$ conclude that "institutionalized and disciplined sports competitions result in positive-sum arrangements, allowing the sport to become a life choice, thus favoring inclusion" (p. 589).

Rangel $^{22}$ states that the problem is not competitiveness, as long as it was as a playful and alternate way to build a spirit of collectivity. Sport as an educational medium not separated from the competitive character since approaching sport without referring to the competition is challenging.

This category marks well the three paths that followed in the Fernanda Keller Project: 1) Challenge - represented in the project in the training of athletes and professional training; 2) Fun - in the formation of the citizen; 3) Companionship - in forming friendship networks and professional networks.

\section{Conclusions}

This study sought to analyze the perceptions of the main actors of the Fernanda Keller Project to identify characteristics in the internal and external environments of the organization, in order to understand the perspectives in its development. The mission of the project is social education, through sports, promoting the socialization and social integration of children and youth based on actions involving sports, health, leisure, and entertainment. Based on the testimonies, social education is understood as the sharing of knowledge between participants and the community itself. The effects of the project on the life of the community permeate the reports of both leaders, coordinators, teachers, and students of the Fernanda Keller Project.

The focus group highlighted challenges, fun, and companionship as central elements. In this case, the idea of social education present in the institutional mission can be characterized as the education based on companionship, challenge, friendship, coexistence, having the sport with the anchor to reach the mission.

In the external environment, the main issue relates to the transfer of funds and accountability. The pieces of evidence in the reports point to the great difficulty of interaction between the project and the city hall, from a particular moment. It can be considered a significant threat to the functioning of the organization the lack of money coming from the city hall. However, the organization understood this as an opportunity and sought partners in the industry, in order to maintain the level of activities.

The organization maintains agreements with state agencies, at different levels, which allows it to expand its actions and services. There is a support network that counts on the industry, the State, and universities, forming a propeller of development ${ }^{26}$.

The forces that present themselves in the internal environment tend to strengthen the organization, considering the examples and commitment of the employees and the direction. In addition to triathlon activities, students receive professional support, with courses related to the area of cycling. Many who sought higher education received scholarships due to the partnership that the organization maintains with universities in the city of Niterói. It was possible to observe that the sporting activities are existing in the Fernanda Keller Project project in the participants the desire to be successful in personal, professional life, as well as in sports. Participants have daily examples of socialization, dedication, and success through the insti- 
tution's employees. They are aware of the importance of the impact of this project on the lives of these children.

There is a commitment on the part of all the team that acts there. There are courses and training courses for the improvement of the employees, in order to reach the objectives and mission of the Institution. The reports highlight the value attributed to the project in the social transformation of youth, community, and professionals involved directly or indirectly in actions.

The project has achieved success and social impact. However, the participation of the city of Niterói has diminished with time. Despite the difficulties encountered, the project has found new partners in the private sector.

Finally, there is a constant struggle and perseverance present in the organization by all employees, who deal with children daily and who have in their own experience the example of how sports can be a great collaborator for the transformation of individuals. The Keller initiative to seek other means to obtain resources was fundamental to the project's maintenance. This posture has led everyone to a positive and involving message that permeates all the reports that this study analyzed.

\section{References}

1. Santos AM, Neto FR, Pimenta RA. Avaliação das habilidades motoras de crianças participantes de projetos sociais/ esportivos. Motricidade. 2013; 9(2): 50-60.

2. Neto EDC, Dantas MMC, Maia EM. Benefícios dos projetos sociais esportivos em crianças e adolescentes. Saúde \& Trans. Soc. 2015; 6(3):109-117.

3. Anshel MH, Muller D, Owens VL. Effects of a sports camp experience on the multidimensional self-concepts of boys. Perceptual and Motor Skills 1986; 61: 1275-1279.

4. Marsh H, and Kleitman S. School athletic participation: Mostly gain with little pain. Journal of Sport and Exercise Psychology 2003; 25: 205-228.

5. Di Palma D, Varriale L, Briganti P, Tafuri D. The importance of sport activities to stimulate an educational management of students with SLD. Journal of Human Sport and Exercise 2019; 14(1): S11-S19. doi:https://doi.org/ 10.14198/jhse.2019.14.Proc1.02

6. Mello A, Neto AF, Votre SJ. Intervenção da educação física em projetos sociais: uma experiência de cidadania e esporte em Vila Velha. Rev. Bras. Ciên. Esp. 2009; 31(1): 75-91.

7. Thomassim LEC. O "público-alvo" nos bastidores da política: um estudo sobre o cotidiano de crianças e adolescentes que participam de projetos sociais esportivos. Tese de Doutorado em Ciência do Movimento Humano, Universidade Federal do Rio Grande do Sul; 2010.

8. Mattos DC, Silva CAF, Lopes JPSR, Capinussu JM. O esporte náutico e a dinâmica da hélice tríplice no projeto Grael: um estudo de caso. Movimento. 2010; 13(3): 221239.

9. Silva OM, Silva CAF. Desenho da rede de um projeto esportivo social: atores, representações e significados. Rev. Bras. Edu. Fis. Esp. 2014; 28(3): 415-428.
10. Marcellino NC. (Org.). Lazer e esporte: políticas públicas. Campinas, Autores Associados, 2001.

11. Werle V. Reflexões sobre a participação nas políticas públicas de esporte e lazer. Motriz: J. Phys. Ed. 2010; 16(1): 135142.

12. Linhales MA. São as políticas públicas para a Educação Física, o Esporte e o Lazer, efetivamente políticas sociais? Motrivivência. 1998; 10(11): 71-81.

13. Parente Filho MS, Melo Filho A, Tubino JG. (Org). Esporte, Educação Física e Constituição. São Paulo, Ibraca, 1998.

14. Azevedo MAO, Gomes Filho A. Competitividade e inclusão social por meio do esporte. Rev. Bras. Cien. Esp. 2011; 33(3): 589-603.

15. Melo MP. Lazer, Esporte e Cidadania: debatendo a nova moda do momento. Movimento. 2004; 10(2):105-122.

16. Tani G, Bento JO, Petersen RDS. Pedagogia do Desporto. Rio de Janeiro, Guanabara Koogan, 2006.

17. Lucena RF, Proni M. (Org.). Esporte: história e sociedade. Campinas, Autores Associados, 2002.

18. Rangel M. A pesquisa de representação social como forma de enfrentamento de problemas socioeducacionais. São Paulo, Ideias \& Letras, 2004.

19. Zaluar A. Cidadãos não vão ao paraíso. São Paulo, Escuta, 1994.

20. Correia MM. Projetos sociais em Educação Física, Esporte e Lazer: Reflexões preliminares para uma gestão social. Rev. Bras. Ciênc. Esporte. 2008; 29(3): 91-105.

21. Bardin, L. Análise de conteúdo. São Paulo: Edições 70, 2011.

22. Rangel, M. Diversidade, diferença e multiculturalismo: valores essenciais da pluralidade social. Niterói: Intertexto, 2011.

23. Santana, MS. Dimensão psicossocial da atividade física na velhice. Revista de Psicologia. 2011; 23(2): 337-352.

24. Bracht V. Sociologia crítica do esporte: uma introdução. Ijuí, Unijuí, 2011.

25. Mittler P. Educação inclusiva: contextos sociais. Porto Alegre, Artmed, 2003.

26. Motta CF, Silva, CAF, Santos RF. Strategies for establishing partnerships between physical education and industry. Journal of Physical Education and Sport. 2018; 18(3): 15241532.

\section{Corresponding author}

Carlos Alberto Figueiredo da Silva: Av. Jornalista Alberto Francisco Torres, 39/301 - Icaraí, 24230-000 Niterói, RJ, Brasil.

E-mail: ca.figueiredo@yahoo.com.br.

Manuscript received on April 11, 2019

Manuscript accepted on February 25, 2020

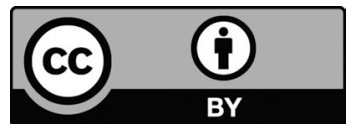

Motriz. The Journal of Physical Education. UNESP. Rio Claro, SP, Brazil - eISSN: 1980-6574 - under a license Creative Commons - Version 4.0 